Florida International University FIU Digital Commons

6-7-2003

\title{
A recital of selected repertoire for the mezzo- soprano voice
}

Pamela Denise Ascroft

Florida International University

DOI: $10.25148 /$ etd.FI14030208

Follow this and additional works at: https://digitalcommons.fiu.edu/etd

Part of the Music Commons

\section{Recommended Citation}

Ascroft, Pamela Denise, "A recital of selected repertoire for the mezzo-soprano voice" (2003). FIU Electronic Theses and Dissertations. 1055.

https://digitalcommons.fiu.edu/etd/1055

This work is brought to you for free and open access by the University Graduate School at FIU Digital Commons. It has been accepted for inclusion in FIU Electronic Theses and Dissertations by an authorized administrator of FIU Digital Commons. For more information, please contact dcc@fiu.edu. 
FLORIDA INTERNATIONAL UNIVERSITY

Miami, Florida

A RECITAL OF SELECTED REPERTOIRE

FOR

THE MEZZO-SOPRANO VOICE

A thesis submitted in partial fulfillment of the

requirements for the degree of

MASTER OF MUSIC

by

Pamela Denise Ascroft 
To: Dean Arthur W. Herriott

College of Arts and Sciences

This thesis, written by Pamela Denise Ascroft, and entitled A Recital of Selected Repertoire for the Mezzo-Soprano Voice, having been approved in respect to style and intellectual content, is referred to you for judgment.

We have read this thesis and recommend that it be approved.

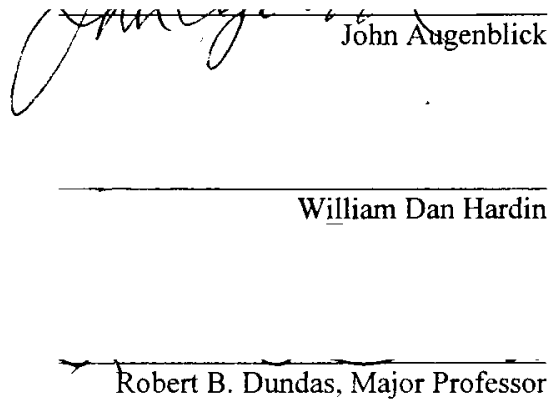

Date of Defense: June 7, 2003

The thesis of Pamela Denise Ascroft is approved.

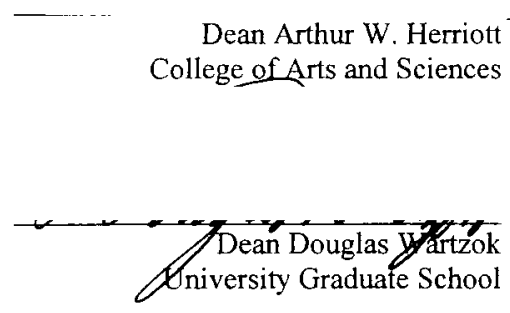

Florida International University, 2003 


\title{
A RECITAL OF SELECTED REPERTOIRE FOR THE MEZZO-SOPRANO VOICE
}

\author{
by
}

Pamela Denise Ascroft

Florida International University, 2003

Professor Robert B. Dundas, Major Professor

Buss und Reu, St Matthew Passion

Es ist vollbracht, St John Passion

O Luna Lucente

Il Mondo della Luna

Gedichte der Königin Maria Stuart

Abschied von Frankreich

Nach der Geburt ihres Sohnes

An die Königin Elisabeth

Abschied von der Welt

Gebet

Simeini kahotam al libeha.....

from Two Songs for Alto and Piano
Johann Sebastian Bach

(1685-1750)

Franz Joseph Haydn

(1732-1809)

Robert Schumann

(1810-1856)
Stefan Wolpe

(1902-2000)

\section{INTERMISSON}

"..i never saw another butterfly.."

Srul Irving Glick

(1934-2000)

To Olga

Yes, That's The Way Things Are

The Little Mouse

On A Sunny Evening

Narrative

The Butterfly 


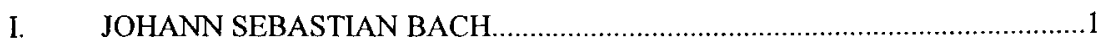

Buss und Reu, St Matthew Passion

Es ist vollbracht, St John Passion

II. FRANZ JOSEPH HAYDN... 5

O luna lucente, Il Mondo della luna

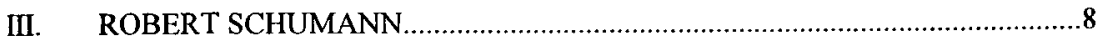

Gedichte der Königin Maria Stuart

Abschied von Frankreich

Nach der Geburt ihres Sohnes

An die Königin Elisabeth

Abschied von der Welt

Gebet

IV. STEFAN WOLPE

Simeini kahotam al libeha, Two Songs for Alto and Piano

V. SRUL IRVING GLICK.

"... i never saw another butterfly..."

To Olga

Yes, That's The Way Things Are

The Little Mouse

On A Sunny Evening

Narrative

The Butterfly

VI. LEILA LUSTIG

Wretched Highway

VII. WILLIAM BOLCOM.

The Actor

George

BIBLIOGRAPHY

APPENDICES 
Johann Sebastian Bach was born in Eisenach is 1685 and died in Leipzig in 1750. He is considered a supreme influence in the development of the laws of music and is among the most prolific composers in history. Bach was the first composer to perfect the concept of equal temperament, which led to the division of the octave into twelve equal semi-tones, thereby making it possible to transpose or effect modulation to virtually any key. The period of Bach's lifetime saw the epoch of the high Baroque, and his name has become synonymous with excellence.

Bach obtained his first church positions as an organist in 1707 in Mühlhausen, and that same year married his cousin Maria Barbara Bach. The couple was destined to have seven children before Maria Barbara's untimely death in 1720 . In 1721, whilst employed as organist by the Duke of Weimar, he married his second wife, Anna Magdalena Wilcken. The couple had a happy life together and produced thirteen children. Of Bach's twenty children, ten survived to adulthood, among them Carl Philipp Emanuel and Johann Christoph who became leading composers of their generation. It was in 1723 that Bach was elected to the post of cantor of the city of Leipzig, and had under his care the musical life of no less than four churches as well as the school at Thomaskirche. It was after his appointment to Leipzig that many of Bach's most significant works were composed. ${ }^{1}$

Among the greatest compositions in the enormous output of Johann Sebastian Bach are his Passions - musical settings of Jesus' suffering and death as related by one of

\footnotetext{
'Nicolas Slonimsky, ed. The Concise Edition of Baker's Biographical Dictionary of Musicians, Eighth Edition. S.v. "Bach, Johann Sebastian." p. 40-42. New York: Schirmer Books, 1994.
} 
the four Gospel writers, or Evangelists. Of the five Bach Passions believed to have existed, only three remain in complete score. The St John Passion (1724) and the St Matthew Passion (1727) are the best known and most frequently performed. The $S t$ Matthew Passion bears a libretto by Christian Freidrich Henrici (1700-1764) with biblical narrative from the Gospel according to St Matthew, and chorale texts by the composer. ${ }^{2}$ The St Matthew Passion is both longer and written to a grander scale than the St John Passion. It is a very traditional setting of the Passion, with Christ's words treated in a quasi-recitative manner in that the accompaniments involve sustained strings and organ more than contrapuntal use of instruments. The aria and arioso settings emphasize the personal response to Jesus' words, either by individual characters or by the crowd.

Bach was scrupulous in his integrity as a musician and as a committed Lutheran, and he wrote each of his passions with deference to the character of the particular Gospel tale. The music in St Matthew Passion gives attention to the concept of Christian witness, the attitudes and feelings of several individuals, as provided by St Matthew's interpretation; St John Passion provides a musically more intimate view of Christ's Passion, a setting which is more internalized, more an exploration of Christ's feelings. History records St John as being the apostle closest to Jesus, and his Gospel setting is a study in Christian compassion. ${ }^{3}$

Buss und Reu is a free text aria scored for alto with flute obbligato. Free text refers to poetry which is not an adaptation or paraphrase of scripture. A calm, lyrical moment in the Passion, the aria is nevertheless a profound expression of the love of Mary

\footnotetext{
${ }^{2}$ Richard Walters, ed. The Oratorio Anthologv: Alto/Mezzo-Soprano. Milwaukee: Hal Leonard, 1994.

${ }^{3}$ Stephen Daw. The Music of Johann Sebastian Bach: The Choral Works. Rutherford, New Jersey:

Fairleigh Dickinson University Press, 1981.
} 
Magdalene for Jesus and her grief at his impending fate, and is a perfect example of Bach's use of aria as an expression of a character's personal commentary. The aria is written in $3 / 8$ time, an example of the Baroque predilection for dance rhythms. Not all dances were in triple meter, of course, but the choice of this particular lilting tempo, emphasized in the flute part, adds to the emotional impact of the aria, bringing out the painful sweetness of Mary's sorrow.

The libretto of the St John Passion is based essentially on Der für die Sünden der Welt gemartere und sterbende Jesus (Jesus tortured and dying for the sins of the world), by Barthold Heinrich Brockes with additional free text poetry from a Passion libretto by Christian Heinrich Postel. The Passion was first performed on Good Friday 1724 at Thomaskirche, Leipzig, where Bach was cantor and organist for the majority of his musical lifetime. Brockes' libretto was extremely popular among $18^{\text {th }}$ Century composers, and was the most frequently set ${ }^{4}$. Es ist vollbracht is a free text aria, and the subject matter is the last moments of Jesus' mortal life. In the text, Jesus is identified positively and powerfully as a Jew; the B section of the aria announces with great joy the victory Christ achieves on the cross, hails Him as a Jewish hero. As a devout Lutheran, Bach would have been familiar with Martin Luther's anti-Semitic philosophy, and his pronouncements upon Jews of his time that refused to convert. Luther recommended that their places of worship be burned, that their prayer books and Talmudic writings be seized and that they be expelled from the cities and towns of Germany. Yet Luther's theology presented a more balanced view than his polemics; Lutherans were taught that Jews were not primarily responsible for Jesus' crucifixion, and that Romans and indeed

\footnotetext{
"Richard Walter, ed. The Oratorio Anthology: Alto/Mezzo-Soprano. Milwaukee: Hal Leonard, 1994.
} 
all people of the time were accountable. ${ }^{5}$ It is this theology, rather than an ugly polemic upon which Bach chooses to model his music, in keeping with the theme of compassion in the Gospel according to St John. Bach scores Es ist vollbracht with cello, an instrument which evokes great emotion is the listener, as it can sound like the cry of a human voice and resonates deeply in our hearts. His use of a dotted rhythm in the slow accompaniment mimics the slowing of Jesus' heart as he dies on the cross and the lyrical yet dignified vocal line begins in minor and ends in major, significant of the Christian belief and hope in Jesus' death and resurrection. The middle section of the aria, in a bright major key extolling the triumph of Jesus over his oppressors exemplifies the composer's joy and surety in his beliefs. Bach's Passion settings truly reflect his great comfort and solemnity in his faith.

\footnotetext{
${ }^{5}$ Michael Marissen. Lutheranism, Anti-Judaism, and Bach's "St John Passion." New York: Oxford University Press, 1998.
} 
Franz Joseph Haydn, known to his contemporaries as "Papa Haydn", was born in Rohrau, Lower Austria, in 1732 and died in Vienna in 1809. He was not from a musical family, but through the generosity of family friends and patrons, he obtained a musical education first as a boy soprano then as a harpsichordist. In 1759 Haydn was engaged by Count Ferdinand Maximillian von Morzin as Kapellmeister for his estate. A fortuitous event in Haydn's life occurred shortly after, when he met Prince Paul Anton Esterházy, who, impressed with the composer's symphonies, engaged him at his palace in Eisenstadt in 1761. Prince Paul Anton died shortly thereafter, and was succeeded by his brother Prince Nikolaus, who engaged Haydn for the new palace at Esterháza. ${ }^{6}$

This system of patronage was the primary method by which a musician attained gainful employment prior to the 19 th century. Though there were the obvious advantages of security, fair payment and decent living conditions for the musician and his family, it was still servitude in that many patrons exerted tight control over their composer's creativity. Haydn's employment for the Esterházy family was long and fruitful, but not without its indignities. He composed symphonies, keyboard music, masses, works for solo instruments, oratorio, and all manner of music in his long and illustrious career as Kapellmeister to the palace. He was a man of good humour and great intelligence, and this is revealed in the astonishing variety of moods - from sparkling to somber - which characterizes his music. In 1802, due to failing health, Haydn resigned his post and spent his remaining years in the comfort of friends and a society which honoured him.

\footnotetext{
${ }^{6}$ Nicolas Slonimsky, ed. The Concise Edition of Baker's Biographical Dictionary of Music and Musicians, Eighth Edition. S.v. “Haydn Franz Joseph." New York: Schirmer Books, 1994. p. 406-408.
} 
Though Haydn is known mostly as an orchestral and instrumental composer and as the father of the Classical style, his genius extended to the song and operatic repertoire as well. Italian opera and Italian singers were highly fashionable in the courts of the mid to late $18^{\text {th }}$ century, thus Prince Esterházy, ever desirous of keeping up with the newest trends, turned his attention from the concert hall to the operatic stage. Il mondo della luna (The World of the Moon, 1777), is a comic opera in three acts with libretto by Carlo Goldoni, and was written as a court entertainment for the Esterhazy family. The librettist worked as a lawyer until the age of forty, by which time his avocation of writing had garnered him enough success that he was able to turn his talent into a full vocation. He wrote over fifty comic libretti, termed dramma giocoso per musica, and revolutionized $18^{\text {th }}$ century comic opera. Goldoni's characteristic of incorporating noble, serious characters into comic plots and dividing the remainder of the characters into fully or partially comic roles gave composers such as Haydn a rich palette of stylistic diversity from which to paint their musical colours ${ }^{7}$. The complexity of characters and situations in Goldoni's libretti inspired Haydn to merge elements of serious Italian opera into the standard comic opera format, leading to a development of the genre which Mozart would later draw upon for his own masterpieces.

The plot of Il mondo della luna concerns the false astrologer Ecclitico who seeks to fool the protective Buonafede into allowing his daughters Clarice and Flamina and their maid Lisetta to marry the husbands they choose (Ecclitico, Emesto and the servant Cecco, respectively). They drug Buonafede and take him to Ecclitico's garden, which he believes is the moon, and sees Cecco as an Emperor and Ernesto as Hesperus. The girls

\footnotetext{
${ }^{7}$ David Wyn Jones, ed. Haydn. New York: Oxford University Press, 2002.
} 
of course are party to the deception, and manage to become betrothed to their respective lovers before Buonafede realizes he has been duped. ${ }^{8}$ It is a typical comic opera plot of the day, with characters such as the buffo bass, the servant characters showing themselves more clever than their masters, with the added element of tribute to the fascination of the time with astronomy. In the age of Enlightenment, science and reason were lauded as the intelligence of the day.

O luna lucente is a pretty and simple hymn to the moon, sung by the virtuous Flamina, but with the wry twist that she knows perfectly well that she is singing not to a mythical moon kingdom, but to Ecclitico's garden. The aria is written in the key of Eflat, and throughout the opera any musical reference to the moon is in this key. Perhaps Haydn chose this E-flat because during the $18^{\text {th }}$ Century, this key was associated with darkness and sleep, or perhaps because Ecclitico refers to the moon as 'la triforme dea' (the goddess who appears in three forms) and Haydn's clever sense of play could not resist the internal joke of choosing a key with three flats. ${ }^{9}$

\footnotetext{
${ }^{8}$ Ibid, p. 165-166.
}

${ }^{9}$ lbid, p. 165 
Robert Schumann's gift to the development of the German lied was to raise the standard for the expression through music of more subtextual layers of poetry. He was born in Zwickau in 1810 and died in Endenich, near Bonn, in 1856. His father was a Saxon bookseller, and young Robert inherited from his father a love of literature and criticism, which grew and developed throughout his life and compositional career and formed a key element in his artistic vision. His family also encouraged his musical education and he began piano lessons at the age of ten.

In 1828 he enrolled at the University of Leipzig as a student of law, and began piano studies with the renowned teacher Friedrich Wieck. Schumann formed a bond immediately with Wieck's daughter Clara, nine years his junior and then a child of ten. Clara was a prodigy and grew to become one of the greatest concert pianists of her time, and a fine composer in her own right. Their friendship blossomed into love as Clara became a young woman, but Friedrich Wieck was vehemently opposed to the relationship. Besides his fear of being replaced in both Clara's affections and in the area of control over her career, Wieck had observed in Schumann traits of emotional instability. His observation was astute, as Schumann himself noted in his writings at the age of twenty-three sudden onsets of angst, difficulty breathing, momentary loss of consciousness and fits of melancholy. ${ }^{10}$ It is clear Schumann suffered from mental illness, though there is much speculation as to a sound diagnosis. It was his inner turmoil

\footnotetext{
${ }^{10}$ Nicolas Slonimsky, ed. The Concise Edition of Baker's Biographical Dictionary of Musicians Eighth Edition New York: Schirmer Books, 1994.
} 
however - his very strangeness - which set Schumann apart as a composer from his contemporaries. His innovative and beautiful output of music amidst his emotional struggles begs examination of the age-old question of the close relationship between genius and madness; are they mutually exclusive or symbiotic? Nevertheless, Schumann in his angst does indeed stand as a symbol of individuality and autonomy, the very Romantic ideals which by the latter years of the composer's life were being eroded by the changing face of society due to industrialization and the emergence in Europe of the nation state. ${ }^{11}$

German composers of the early to mid-nineteenth century who embraced the ideals of nature, elevated emotions, and who favoured folk tales and gothic mystery were described as romantic, and Schumann is considered by some to be the most romantic of them all. His particular blend of unexpected modulations, exploration of chromatic harmony, spontaneous bursts of pianistic virtuosity coupled with his deep attachment to great poetry and his vast literary knowledge make his songs rich and lush in texture. His songs did not employ a surface lyricism or clear tonal patterns intended to lull the listener with a sense of safety and familiarity, however, they are contained within a recognizable tonal framework. His great outpouring of song truly began in 1840 , the year he was finally permitted by the courts to marry his beloved Clara Wieck. His greatest song cycles were written in this year, as well as many individual songs.

Gedichte der Königin Maria Stuart (Poems of Mary, Queen of Scots), Op. 135 was written in 1852 , and is significant as his final vocal work. The songs are dramatic in

\footnotetext{
${ }^{11}$ R. Larry Todd, ed. Schumann and His World. S.v. "History, Rhetoric, and the Self: Robert Schumann and Music Making in German-Speaking Europe, 1800-1860". Botstein, Leon. Princeton: Princeton University Press, 1994.
} 
tone, and all but one end in the key of E minor, regardless of what key area Schumann explores within the body of each individual song. The texts are translated, purportedly, from the French of Mary Stuart, written during her incarceration in the Tower of London. Mary was the daughter of James V of Scotland and Marie de Guise. In 1558 she married the Dauphin, who later became King Francis II of France. Mary was also greatgranddaughter to King Henry the VII of England, and thus disputed Queen Elizabeth's claim to the throne when the latter came to power. A power struggle ensued, and the English Queen's machinations led to Mary being accused of murdering her own husband, and being extradited to England where she was to be incarcerated for nineteen years in various English castles. Finally, in 1587, a regretful but powerful Queen Elizabeth signed the death warrant, and Mary, Queen of Scots, devout Catholic, was beheaded on February $1^{\text {st }}, 1587$. She was forty-seven years of age. ${ }^{12}$

The themes of farewell, of sleeplessness, agitation, and a solemn acceptance of her fate in Mary's text parallels Schumann's own knowledge that his mental stability was questionable, and that his own fate of madness was fast approaching and inevitable. The first piece is the most Romantic in style - a sad melody full of nostalgia - and the running sixteenth note accompaniment personifies the water, which takes Mary away from France, her beloved childhood land. Schumann departs in the second piece from the multi-layer Romantic style and presents essentially spare, declamatory song reminiscent of Elizabethan monody ${ }^{13}$. The music is truly text-driven, the rhythm of language dictating form and movement. The third piece, an emotional letter to Queen Elizabeth,

\footnotetext{
${ }^{12}$ Dietrich Fischer-Dieskau. Robert Schumann Words and Music: The Vocal Compositions. Portland: Amadeus Press, 1981.

${ }^{13}$ Ibid, p. 198.
} 
leaves no room for breath so intense, fraught and fragmented is its phrasing. In this piece we see the breakdown of Schumann's thought process reflected in Mary's utterances, at once sorrowful, accusatory and self-recriminating. The dignified and courtly "Farewell to the World" is nevertheless an abyss of sorrow and resignation. The most melodic element is the brief, descending one and a half bar phrase which heralds each verse. The final song is a prayer of resignation touched with a quietly desperate plea for salvation for a last-minute reprieve. Once again, Schumann chooses a sparse texture and declamatory style, a calm and soft voice amidst the cacophony of voices in his tortured mind. Indeed, it is a whispered protest against the clamour of both the new industrial world around him and the noisy new music of the 1850's.

Robert Schumann died in a sanatorium, having voluntarily committed himself two years prior to his death after a suicide attempt. He remained devoted to Clara, though he often did not want to see her or the children. He wrote, however, that being able to present Clara with Gedichte der Königin Maria Stuart as his last gift of song gave him great pleasure. ${ }^{14}$

\footnotetext{
${ }^{14}$ Ibid, p. 198.
} 
German born composer Stefan Wolpe was a student of Anton Webern, and counted among his influences Scriabin, Hindemith and Satie. Born in 1902, he began formal musical studies in 1919 at the Berlin Hochschule für Musik, and graduated in 1924. He quickly became involved in the vibrant choral and theatrical life of 1920 's Berlin and also in the controversial political scene. He was a social activist and composed songs on revolutionary themes, highlighting the plight of workers and promoting socialist philosophy. When the dark wave of the anti-Semitic Nazi regime came to power in 1933, Wolpe went first to Vienna, then on to Palestine in 1934. He taught at the Jerusalem Conservatory until 1938, at which time he immigrated to the United States. He devoted himself mainly to teaching and held several prestigious posts, including the Philadelphia Academy of Music, Black Mountain College and Long Island University until his death in 1972. ${ }^{15}$ In coming to America, Wolpe joined the legions of European Jewish composers who fled Nazi persecution in the 1930's and brought their talents to North American universities, concert halls, the Hollywood film industry and the Broadway stage.

Stefan Wolpe was considered a leading avant garde composer of his time, yet his music is rarely heard today because of its ferocious difficulty. The composer himself was a virtuoso pianist, and thus his works for voice and piano are highly pianistic, the voice becoming more the accompanimental instrument. His work is crisp and rhythmically

\footnotetext{
${ }^{15}$ Nicolas Slominsky, ed. The Concise Edition of Baker's Biographical Dictionary of Musicians, Eight Edition. S.v. "Wolpe, Stefan." p. 1129-1130. New York: Schirmer Books, 1994.
} 
complex, as well as searingly intense. The time in which he studied was dominated by the giants of the Second Viennese School - Schoenberg, Berg and Webern. Though he experimented with twelve-tone composition, he eventually distanced himself from serialism, claiming this system, based on the constant circulation of all twelve pitch classes, was limited and rudimentary. ${ }^{16}$ His work was more motivic, and highly dependent on context. In other words, his compositional thought was autonomous of any particular school of thought, as each work was an entity unto its own context, its form and organization dictated by that which it was - a very existential view of nusic.

Wolpe's Two Songs for Alto and Piano were composed in his Palestine period in the mid 1930's - the exact date is not known - but were not published until 1948, coincidentally the year of the founding of the State of Israel. The Hebrew text is from the Shir ha Shireem (Song of Songs), chapter 8 , number 6. Song of Songs is part of the Tanahk or Writings, and is chanted during Passover, the time of spring and renewal. Though the poetry is sensual, it is in essence a metaphor for the love of God for His people and a celebration of God's liberation of Israel from the confines of Egypt. In the second song, the strong and bold sentiment of the text is echoed in the thick piano texture and the dynamically strident vocal line. Prior to his studies in Vienna, Wolpe had written several socialist worker songs and employed traditional triadic forms. This later song seems to be an amalgamation old and new: of essentially triadic chords to which nonchord tones have been added to thicken texture and displace a sense of tonal centre, and of a twelve-tone series in a vocal line which leaps and plunges to the extremes of the

\footnotetext{
${ }^{16}$ Reinhold Brinkmann, Christoff Wolff, ed. Driven Into Paradise: The Musical Migration from Nazi Germany to the United States. Berkeley: University of Califomia Press, 1999.
} 
pitch range. The spirit of the piece in its textual context also seems to convey a sense of ancient and modern. The strength and sensuality, extremes of the emotions of love and jealousy portrayed in the Hebrew poem, the life and death intensity - these are aspects of the life Wolpe witnessed in his sojourn in Palestine. As once the ancient Jewish people had found their home in the desert after the flight from Egypt, they found in the 1930s a refuge from Nazi persecution in modern Palestine. The composer expresses with his contracting and expanding music, his strong motivic sense and the intensity of his textual choice the harsh desert life and determined faith of the Zionist settlers.

The Two Songs for Alto and Piano explore the two opposing compositional styles, traditional and twelve-tone, which Wolpe later was able to synthesize into his own brand of genius, and the passion and strength found in the Song of Songs. It is unclear why these songs were not published until 1948, but it is interesting to note that these powerful songs by a composer who had been forced to flee the country of his birth due to the blight of persecution were brought to light in the same year the long held dream of Zion - the establishment of a Jewish homeland - became a reality in the founding of Israel. 
Srul Irving Glick's “...i never saw another butterfly..." is a cycle of six songs set to the poetry of the children of the Theresienstadt concentration camp. These songs mark a turning point in Glick's compositional style, and the relationship between text and music is key to understanding Glick's mature trademark style of synthesizing classical Western music, Yiddish folk music and traditional Jewish liturgical melodies.

In 1790 , in the central mountains of Bohemia where the river Elbe flows into the Orhe, the Hapsburg Emperor Joseph II built a fortress, a walled garrison tcwn that he named for his mother, Maria Theresa. The local people called it Terezin. In 1939, German troops crossed the Czech frontier and reached Prague; Bohemia and Moravia were made German protectorates; Czechoslovakia was dismembered and absorbed into the greater Reich. The inhabitants of Terezin at this time numbered 3,700, including ten Jewish families. In October 1941, Terezin became Theresienstadt, a ghetto to be administered by the SS, guarded by Czech gendarmes and run internally by a Jewish council of elders. ${ }^{17}$

In order to understand the workings of Terezin, it is necessary to illuminate the background of the ideology behind the camp's creation. Any understanding of Terezin, its inhabitants, its artists, its children and the spirit of creativity and hope which shone like a single candle within a well of darkness can only be facilitated by a discussion of the forces which brought it about.

\footnotetext{
${ }^{17}$ Hana Volavková, ed. ... I never saw' another butterfly... Children's Drawings and Poems from Terezin Concentration Camp 1942-1944. New York: Schocken Books, 1993.
} 
To the Nazi ideology, the mission of waging war against European Jewry was paramount. Anti-Semitism is obviously stated in the earliest writings of Adolph Hitler. In Mein Kampf, Hitler states: "I believe that I am acting in the spirit of Almighty God; in defending myself from the Jews, I am doing God's work."18 Two of the central questions which have puzzled historians concerning the Holocaust are firstly, what internal forces drove one man to such monumental hatred of one section of the population that he made it his life's mission to destroy them, and secondly, if purging Europe of the Jewish people was central to the ideology and manifesto of the Nazi party, why hide it from the world? Why not glory in the success of the death camps in exterminating six million Jews as much as the party gloried in its military victories over the Allied forces?

The great majority of Terezin's occupants were artists, musicians, and intellectuals. Cultural life flourished amongst the filth and sickness of the ghefto. Concerts, lectures, plays abounded; the library held 60,000 books. Bauhaus trained artist Friedl Dicker-Brandeis taught painting to the children, encouraging them to express their feelings through words and drawings. Violinist Alma Rose, immortalized in Arthur Miller's Playing For Time, led an orchestra under the watchful eye of SS guards. Most of the musicians had already served the Jewish people during the 1930 s as members of the Jüdische Kulturbund, the Nazi-approved society where Jewish musicians, actors, technicians and lecturers could legally work and provide the Jewish population with the only cultural and entertainment venues they were permitted to attend. The Kulturbunds were all disbanded, however, after the Final Solution, and those who had remained in

${ }^{18}$ Ibid, . p. xii 
Europe and had escaped the death camps now waited for the dreaded pink papers, which were issued for 'transport', which meant certain death in the Eastern camps. ${ }^{19}$

The Soviet Army liberated Theresienstadt on May $8^{\text {th }}, 1945$. There remained in the camp 16,832 Jews. 33,456 had died in the ghetto; 88,202 had been transported to death camps in the East. Of the 15,000 children deported from Theresienstadt to Auschwitz, 100 survived, none under the age of fourteen. A man named Willy Groag was appointed coordinator of the children and youth department of Theresienstadt. He was entrusted with two suitcases full of childrens' drawings and poems. He gave them to the Prague Jewish community authorities, who left them to sit on a shelf for ten years.

The suitcases were rediscovered in 1955 , and their contents have since been exhibited all over the world, and have inspired many artists and composers. Terezin now shows little trace of those ghetto years. ${ }^{20}$ It is once again a place of beauty, and the butterflies have returned.

Canadian composer Srul Irving Glick was born in Toronto in 1934, and died in 2000. His parents were Russian born Jews who immigrated to Canada in 1924. His father was a cantor, and his brother Norman became a professional clarinetist. Glick grew up, therefore, with a mixture of traditional chazanut, Yiddish folk melodies and the influences of the great composers of Western music history, especially Mozart, Beethoven and Brahms. As a boy, Glick joined the Habonim, the Labour Zionist Youth Club, and learned many Chassidic and Israeli folk songs. All of this is heard in his

\footnotetext{
${ }^{19}$ Martin Goldsmith. The Inextinguishable Symphory. New York: John Wiley \& Sons, Inc., 2000. ${ }^{20}$ Hana Volavková, ed. ...I never saw another butterfly... Children's Drawings and Poems from Terezin Concentration Camp 1942-1944. New York: Schocken Books, 1993. p. XX.
} 
music, which by and large is a synthesis of the lyrical and the dissonant, light and dark.

To quote the composer: "Jewish folk music has made a most powerful impression on me. It's multi-faceted. It can appear happy while it's tragic. It's almost always laughter through tears. $" 21$

Glick received his Bachelor of Music and Master of Music in composition from the University of Toronto, studied for two summers at Aspen with Darius Milhaud, and then in 1959 studied for a year in Paris with Louis Saguer and Max Deutsch. From 1962 to 1986 he was an award-winning producer for $\mathrm{CBC}$ Radio. He also taught theory and composition at the Royal Conservatory of Music in Toronto and at York University. In 1969 he became conductor of the choir at the Conservative synagogue Beth Tikvah, and also served as the only composer in residence in a synagogue in Canada. He wrote liturgical music and Yiddish folksong arrangements for the choir, and toured throughout Canada, the US and Israel. ${ }^{22}$

The great majority of Glick's works were written on commission, and in 1969 the $\mathrm{CBC}$ commissioned him to write a song cycle for the great Canadian contralto, Maureen Forrester. This work became '... i never saw another butterfly...'. The songs are highly representative of Glick's style. The song cycle is a pivotal work for Glick in that it is the high water mark for his mature style, which became his trademark - western music influenced by the Jewish spirit.

Glick has been called a neo-romantic. This concept is accurately represented in the songs, as lyricism dominates the vocal line and the impetus of the music is text

\footnotetext{
${ }^{21}$ Frank Rasky. "Prayer Gives Inspiration, Psychic Energy to Glick." The Canadian Jewish News. 23 April 1987, 34 .

22 Ibid, p. 34 .
} 
driven. Innocence and a pervasive sense of hope saturate the voice part, representing the voices of the children. In the piano accompaniment Glick uses polytonality - none of the pieces bears a key signature - and the dissonant note clusters give us not only a constant sense of the underlying, insidious presence of fear, horror and tumultuous emotions present in the subtext of the poems, but show Glick's process as he struggled with the opposing musical forces of his upbringing and training amidst the atonal, experimental, creative explosion in post- World War II Western music.

After '... i never saw another butterfly... ' Glick essentially left atonality behind and became comfortable in his particular brand of synthesis. He wrote in 1991 "...today, everything I write has this stamp. Within the classical music structure, I'm conscious of nusach (improvisational prayer on a single line melody), the motifs that represent feeling in prayer and the Yiddish/Chassidic traditions that developed out of Hebrew prayer., ${ }^{23}$ To non-Jewish ears his music is recognizably Canadian and representative of the western idiom which has been discussed here, but to Jewish ears his music evokes a visceral reaction to melodies embedded within the music, coming out of the shared memory of Yiddish song, cantorial improvisation, and the emotional impact of laughter through tears, of a tradition which has survived persecution and fragmentation for over 5000 years.

\footnotetext{
2. Paula Citron. "Srul Glick a Dominant Force on Canada's Musical Scene." The Canadian Jewish News 24 January 1991, 63.
} 
Though born in Kentucky (1944), Leila Lustig has lived and worked in Canada for the majority of her professional life and holds a place of high regard among Canada's living composers. Wretched Highway was commissioned in 1990 for the annual interdisciplinary conference "Two Days of Canada" at Brock University in Ontario, where Ms Lustig was then faculty. The text is by Brock University French professor Alexandre Amprimoz who received the Order of the Golden Palm from the French government for his services to French literature. Since there is not sufficient research material available on Ms Lustig's composition (being so recent), the opinions and information expressed in this chapter are from the analysis of this researcher.

The text of Wretched Highway is an ironic statement on the condition of the Eastern Canadian section of the Trans-Canada highway. This highway runs the breadth of Canada from Victoria, British Columbia to St John's, Newfoundland. As the highway passes through Southem Ontario, it skirts the American border, close to the industrial city of Detroit and Lake Michigan, one of the Great Lakes shared by Canada and the United States. Amprimoz describes this area as "...the canadian (sic) side of the detro(y)it river where day and night from the american (sic) factories fall a grey manna...". ${ }^{24}$ The thrust of the poet's message is in this line; his concern and sadness over the pollution created by more than a century of heavy industry and its impact on the Canadian environment. There is irony in calling the pollution "grey manna", for as much as the smoke and chemical waste damages the environment, the jobs the factories provide put bread on the table for many families on both sides of the border. The text is infused with many such

\footnotetext{
${ }^{24}$ Alexandre L. Amprimoz, Leila Lustig. Wretched Highway. Ontario: Leila Lustig, 1990.
} 
comments, for example, "...the sun shines through the mouth of a broken bottle...". ${ }^{25}$ The poet expresses the beauty of sunlight refracted through glass, but it is not glass in the window of tidy house or church, but an ugly piece of trash carelessly left behind to deface nature. Amprimoz goes on to describe the wind echoing through the desecration of one of the lovelier spots, saying it could have been a spot of beauty ".... without the things we all know....". ${ }^{26}$ Here he asks the reader to accept the responsibility we all carry for this sad situation, whether we polluted the area directly with our carelessness and lack of vision, or whether we did nothing to stop those who did.

Leila Lustig scores Alexandre Amprimoz's poem for voice, piano and clarinet. She uses the three instruments to highlight various different aspects of the poem's text and subtext. Though the piece bears no key signature, the vocal line is essentially in Fmajor and is quite straightforward. The composer adds accidentals and non-chord tones to foster a sense of a B section to the piece, but does not actually modulate into another key. The clarinet has a blues feel, and echoes the voice frequently in rhythm if not in pitch. The addition of this instrument adds a mournful tone, a gentle reprimand like the sighing of the land and water which has been so abused. The piano maintains a rolled chord figure, rather like the strumming of a guitar, and follows a strict rhythm. This is the underlying musical drive of the piece, and mimics the constant motion of cars on the highway and the continuous grind of the factory machines.

\footnotetext{
${ }^{25}$ lbid,. p. 7.

${ }^{26}$ Ibid,. p. 8.
} 
Wretched Highway is a true ensemble work. Though it would appear the three instruments are only barely related to each other in terms of rhythm and pitch organization, no one line can stand alone as a solo - only through this odd juxtaposition of clashing sounds does the piece work effectively. Ms. Lustig supports the poet's theme of disassociation and destruction with her three-layered approach, but by composing the parts so that they are mutually dependent she also strives to show that the responsibility for both the pollution and the clean-up falls on all our shoulders. 
William Bolcom, born in Seattle in 1938, fell in love with jazz and ragtime piano at an early age, and when barely a teenager played for the vaudeville shows which passed through town. He received a full academic musical education, however, and graduated with a Doctor of Musical Arts from Stanford University in 1964, counting among his teachers Darius Milhaud and Leland Smith. Bolcom's compositional output spans a wide variety of styles and methods including serial thematics, musical collage and microtonal electronics. He has received many honours for his excellent works for orchestra, piano, chamber ensembles and operas. ${ }^{27}$ He has never lost his penchant for either the popular music of America's past or the proletarian music of the smoky cafes of Europe prior to World War II. Elements of both these genres colour much of Bolcom's work, prompting his collaborator and friend Arnold Weinstein to comment "Milhaud found Bill and brought him back alive to highbrow music, though he never lost his lowbrow soul. 28

Bolcom and Weinstein set out between 1977 and 1983 to write songs to be sung in a loosely themed revue by Bolcom's wife, mezzo-soprano Joan Morris. They wished also to honour the European tradition of cabaret and expand its horizons with modern harmonies. Cabaret is an artistic and social phenomenon which flourished in Europe over a period of about fifty years, from the opening in 1881 of the famous Chat Noir in Paris to 1930's Berlin, when political crises stifled freedom of thought and expression. However, the roots of the cabaret aesthetic, the idea of using music and words to discuss

\footnotetext{
${ }^{27}$ Nicolas Slonimsky, ed. The Concise Edition of Baker's Biographical Dictionary of Musicians Eighth Edition. New York: Schirmer Books, 1994.

${ }^{28}$ William Bolcom and Amold Weinstein. Cabaret Songs, Vols. I and 2. Milwaukee: Edward B. Marks Company, 1985.
} 
the news of the day which was not politically correct for the local newspapers, extend as far back as Elizabethan times. In taverns and on street corners, balladiers sang the stories of the streets and the courts for all to hear. Alongside the pamphleteers of the $17^{\text {th }}$ and $18^{\text {th }}$ centuries such as Dryden, Bacon and Newton were the popular composers investing drinking songs with political wit and social comment. ${ }^{29}$

Growing out of the Viennese cafe tradition and the advent of lieder in $19^{\text {th }}$ century Germany came Arnold Schoenberg's pre-World War I Brettl-Lieder (Cabaret Songs). This illustrious line came to rest amongst the mayhem of 1920's Berlin with the great masters of the cabaret idiom, Kurt Weil and Bertholdt Brecht. This extraordinary team vowed to "write for today, to hell with posterity", and thinly disguised the ideas of Marx and Freud while warning of the encroaching evil of Fascism anti-Semitism. Under the paint, powder and feather boas lurked a very serious message. ${ }^{30}$

ln The Actor and George, Bolcom and Weinstein capture the style of the cabaret singer. The only set is the piano and an empty stage; the entire show is contained in the delivery of the performers. The musical language of The Actor is highly dissonant and percussive. There are short phrases in the voice, punctuated by crashing chord clusters on the piano. The text tells the story of a man who "dies for a living,"31 and is reminiscent of the great actors of the late $19^{\text {th }}$ century such as Henry Irving and Ellen Terry, to whom melodrama was the breath of life. In a more modern context, The Actor is also linked in style to some of the more exaggerated forms of performance art seen in

\footnotetext{
${ }^{29}$ Ibid, p.3.

${ }^{30}$ Ibid, p. 3.

"Ibid. p. 50.
} 
the 1960s. Each time the word 'dies' appears, Bolcom uses the dynamic marking of $s f$, (sforzando), indicating a sudden explosion of sound.

In George, Bolcom shows us a more romantic and tonal side to his writing, with lush chords, sweeping piano solos and intentional parody of Puccini opera. "George," or "Georgia" as he prefers to be called, is a transvestite performer who fancies himself a diva of the operatic stage. Once again, the character is large and lively, and the broad musical gestures in the vocal line give much scope for a well-developed characterization. It is the intimacy of the cabaret ideal, however, which gives the piece its impact. Bolcom has embedded within his grand gestures and larger-than-life Georgia a sweet sadness, an element of tragic amongst the comedic, a vulnerability which causes the audience to care about what happens to poor, self-deluded Georgia. There is a delicacy in the vocal writing, and it is here that Bolcom pays his greatest homage to cabaret, for it is when the words and music express what cannot be said that the song is elevated above musical comedy and becomes a true cabaret song. 


\section{BIBLIOGRAPHY}

Bolcom, William and Amold Weinstein. Cabaret Songs Volumes 1 and 2. Milwaukee: Edward B. Marks Company, 1985.

Citron, Paula. "Srul Glick a Dominant Force on Canada's Musical Scene." The Canadian Jewish News. 24 January 1991, 63.

Crawford, Richard. America's Musical Life. New York: W.W. Norton \& Company, 2001 .

Daw, Stephen. The Music of Johann Sebastian Bach: The Choral Works. Rutherford: Fairleigh Dickinson University Press, 1981.

Brinkmann, Reinhold, Christoff Wolff, ed. Driven into Paradise. Berkeley: University of California Press, 1999.

Fischer-Dieskau, Dietrich. Robert Schumann Words and Music: The Vocal Compositions. Portland: Amadeus Press, 1981.

Goldsmith, Martin. The Inextinguishable Symphony. New York: John Wiley \& Sons, Inc., 2000.

Hitchcock, H. Wiley. Music in the United States: A Historical Introduction. New Jersey: Prentice-Hall, Inc., 1974.

Jones, David Wyn, ed. Haydn. New York:

Oxford University Press, 2002.

Marissen, Michael. Lutheranism, Anti-Judaism, and Bach's St. John Passion. New York: Oxford University Press, 1998.

Mose, Peter. "Neo-romantic Glick's Life, Works Celebrated." The Toronto Star. November $26^{\text {th }}$, (1991).

Rasky, Frank. "Prayer Gives Inspiration, Psychic Energy to Glick." The Canadian Jewish News. 23 April 1987, 34.

Todd, R. Larry, ed. Schumann and His World. Princeton: Princeton University Press, 1994.

Volavková, Hana, ed. ...I never saw another butterfly... Children's Drawings and Poems from Terezin Concentration Camp 1942-1944. New York: Schocken Books, 1993. 
Walters, Richard, ed. The Oratorio Anthology: Alto/Mezzo-Soprano. Milwaukee: Hal Leonard Corporation, 1994. 


\section{TRANSLATIONS}

\section{Buss und Reu}

Du lieber Heiland du, wenn deine Jünger töricht streiten dass dieses fromme Weib mit Salben deinen Leib Zum Grabe will bereiten; So lasse mir inzwischen zu, von meiner augen

Tränenflüssen ein Wasser

Auf dein Haupt zu giessen

Buss und Reu

knirscht das Sündenherz entzwei dass die tropfen

Meiner Zähren angenehme Spezerei, treuer Jesu, dir gebähren.

\section{Est ist vollbracht}

Est ist vollbracht,

O Trost vor die gekränken Seelen, die Trauer nacht, Lässt mich die letze Stunde zählen. Der Held aus Juda siegt mit Macht, und schliesst den Kampf.

\section{O Luna Lucente}

$O$ luna lucente,

Di Febo sorella che candida

E bella risplendi lassù

Deh f ache nostrum occhi

S'accosta no a tuoi

E scopriti a noi che cosa sei tu.

\section{Grief and Pain}

You, beloved Saviour, when your disciples foolishly quarrel, because of this devout woman with ointment your body for the grave will prepare; so allow in the meantime, from my eyes a flood of tears on your head to shower.

Repentance and regret grind the sinful heart asunder, as the drops of my tears a pleasant spice Faithful Jesus, you bring forth.

\section{It is the end}

It is finished, O comfort for the ailing souls, the night of sorrow, Allows me the final hour to count. The hero of Judah triumph with might, And concludes the battle.

\section{Dear shining Moon}

Dear shining moon, Sister of Phoebus that candid and beautiful shines in the highest.

Oh, alas, make our eyes draw near and reveal yourself to us as what you are. 


\section{Abschied von Frankreich}

Ich zieh dahin, dahin!

Ade, mein fröhlich Frankenland, wo ich die liebste Heimat fand, du meiner Kindheit Plegerin! Ade, du Land, du schöne Zeit. mich trennt das Boot vom Glück so weit!

Doch trägt's die Hälfte nur von mir ein Teil für immer bleibet dein, mein frölich Land, der sage dir, des Andern eingedenk zu sein! Ade!

Nach der Geburt ihres Sohnes

Herr Jesu Christ, den sie gekrönt mit Dornen

beschütze die Geburt des hier Gebor'nen. Und sei's dein Will', lass sein Geschlecht zu gleich lang herrschen noch in diesem Königreich und alles, was geschieht in seinem Namen, sei dir zu Ruhm und Preis und Ehre, Amen.

\section{An die Konigin Elisabeth}

Nur ein Gedanke, der mich freut und quält,

hält ewig mir den Sinn gefangen,

So dass der Furcht und Hoffnung Stimmen resound,

Als ich die Stunden ruhelos gezählt.

Und wenn mein Herz dies Blatt

zum Boten wählt,
Farewell to France

I am going away, away!

Farewell, my happy France.

Where I found the lovely homeland

You the guardian of my childhood!

Farewell, $O$ land, $O$ happy time, The ship bears me far away from joy!

Yet it takes but half of me:

One part will be for ever yours,

My happy land, recalling to you

The memory of that other self?

Farewell!

After the birth of her son

Lord Jesus Christ, whom they crowned with thorns

Protect this new born boy, And, if it be thy will, let his race

Long rule in this realm

And let all that is done in his name Be to thy glory, praise and honour, Amen.

\section{To Queen Elizabeth}

One thought alone gladdens and grieves me

And dominates my mind,

So that the voices of fear and hope

When sleepless I count the hours.

And when my heart chooses this letter as messenger, 
und kündet, euch zu sehen, mein Verlangen,

dann, teurer Schwester, fasst mich neues

Bangen,

Weil ihm die macht, es zu beweisen, fehlt.

Ich seh, den Kahn im Hafen fast geborgen,

Vom sturm und Kampf der Wogen festgehalten,

Des Himmels heit'res antlitz nachtumgraut

So bin auch ich bewegt von Furcht und Sorgen,

Vor euch nicht, Schwester.

Doch des Schicksals Walten

Zerreisst das Segel oft, dem wir vertraut.

\section{Abschied von der Welt}

Was nützt die mir noch zugemessne Zeit

Mein Herz erstarb für irdisches Begehren,

nur Leiden soll mein schatten nicht entbehren,

mir blieb allein die Todesfreudigkeit

lhr Feinde, lasst von eurem Neid:

mein Herz ist abgewandt der Hoheit ehren,

des Schmerzes Ubermass wird mich verzehren;
Revealing how I long to see you,

Then, dear sister, anguish seizes me,

Because the letter lacks the power to prove it.

I see the boat half hidden in the harbour,

Held back by the storm and warring waves

And heaven' serene face blackened by night.

So am I likewise beset by cares and fear, Not of you, dear sister. But the force of fate. Often lacerates the sail in which we trust.

Farewell to the World

What use is the time still allotted me

My heart is dead to earthly desires,

My spirit is severed from all but sorrow.

The joy of death alone remains.

Cease envying me, $O$ enemies:

My heart abjures all honour and nobility.

Excess of anguish will devour me. 
bald geht mit mir zu Grabe Hass und Streit.

Ihr Freunde, die ihr mein gedenkt in Liebe, erwägt und glaubt, dass ohne Kraft und Glück kein gutes Werk mir zu vollenden bliebe.

So wünscht mir bessre Tage nicht zurück, und weil ich schwer gestrfet werd'hienieden,

erfleht mir meinen Teil am ewgen Frieden!

Kahotam al zroeha zroeha Kia za kamavet aza ahava Kasha k'shol kishol kasha kina

$\mathrm{Ki}$ aza kamavet aza ahava Kasha k'shol kishol kasha kina. Rishafeha rishafeha rishpeiesh

Rishpei esh shalhevet shalhevet ya.
Hatred and schism will soon be buried with me.

O friends, who will remember me with love, consider and believe that without power or fortune there is nothing good I can achieve.

So do not wish for the return of happier days, And because I've been sorely punished here on earth, Pray that a share of eternal peace

Might be mine!

For love is a strong as death,

Jealousy is cruel as the grave;

The coals thereof are coals of fire,

Which hath a most vehement flame. 